\title{
Simon Pearce: A Teaching Case
}

Michael A. Novak, (Email: michael.novak@umb.edu), University of Massachusetts Boston Jeanne M. Aurelio, (Email: jaurelio@bridgew.edu), Bridgewater State College

\begin{abstract}
Simon Pearce is the founder and president of Simon Pearce Glassworks (SP). His primary but not sole business is the design, manufacture and sale of his upscale glassware. In 1981 after ten years of building a successful business in Ireland but frustrated with the obstacles he faced, he moved his business to Vermont. In 1992, SP had annual retail sales of \$5 million; in 1996, approximately $\$ 12$ million; and in 2001, \$30 million. Not bad for a man of 56 who was expelled from school at age 15. After years of hard work, risk, and struggle, his creativity and business acumen brought him financial success but not the peace and happiness he expected. Due in part to recent business decisions by Simon, the 2001 recession, and 9/11, SP faces, among several serious business problems, a drastic decline in sales at a time SP can ill-afford a marginal decline. At the same time, Simon is no longer interested in growing the business. What should he do? The case is useful in courses or course modules on creativity, innovation, and entrepreneurship.
\end{abstract}

\section{Introduction}

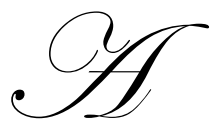

$\mathrm{t}$ age 15, Simon Pearce was expelled from the last of several schools he attended. Four decades later, he is the founder and president of the very successful Simon Pearce Glassworks. He has become the 'Ralph Lauren' of the upscale glass industry: a major brand name of a product that is recognized as hip and desirable, expensive but affordable (Johnson, 1996). With headquarters in Vermont, there are four Simon Pearce glass factories, two restaurants, a pottery business, a ceramic business, a hydroelectric plant, twelve Simon Pearce retail stores and over 270 other retail stores across the country that sell his unique, handblown glassware. In 1992 the company had annual retail sales of $\$ 5$ million; by 1996, $\$ 12$ million; and in 2001, \$30 million. His retail stores are located at some exclusive addresses: Park Avenue and Soho in New York City; Newbury Street in Boston; Princeton, New Jersey; Westport and Greenwich, Connecticut; West Chester, Pennsylvania; and Bethesda, Maryland.

After years of hard work, risk, and struggle, his creativity and business acumen have brought him the fame and financial success of his dreams but not the satisfaction or happiness he expected. Due to the 2001 recession and to some recent major business decisions, his business faces some serious problems. However, growing the business is no longer his passion.

\section{The Art of Simon Pearce}

The unique glassware designed by Simon Pearce-wine glasses, goblets, tankards, bowls, vases, pitchers, lamps, candlesticks, etc.--is clear, unleaded crystal, completely hand blown and finished. Clarity is one of the unique qualities of glass that intrigues Simon, requiring high quality raw material. Low quality clear glass is easy to produce, using less pure raw material and/or a high degree of machining. High quality clear glass is difficult. While color can camouflage a multitude of flaws, every element from raw materials to the tools being used must be perfect for true clarity to be achieved. Being hand blown and finished, each vase, glass, and bowl is unique, varying slightly from apparently identical pieces. The rough cross underneath each piece of glass, made by the pontil iron that holds it in place as it is finished, symbolizes the unique nature of each piece. For that reason, the cross is left as the Simon Pearce trademark.

Readers with comments or questions are encouraged to contact the authors via email. 
The quality of the glass used combined with the hand-finishing produces remarkably strong pieces that tolerate much more wear and tear (abuse) than typical, machine-finished glassware. In Simon's words, his glass is "simple, functional, user-friendly, with the quality and character of early glass" (Johnson, 1996: 21). Douglas Heller, director of the Heller Gallery in Manhattan, describes Simon's glass as the Steuben glass for Everyman. In his designs, "he's exploring a traditional sensibility. His forms are sturdy, straightforward, and honest. The familiarity is part of the appeal" (Johnson, 1996: 21). The inspiration for his designs is rooted in the everyday, antique glass Simon began collecting in his early years. The automation of the Industrial Revolution turned affordable original glass into an endangered species. Yet, Simon admired it for the human touch that gave each piece individuality and character and decided to recreate it in his designs. The lines of his glass are not delicate or fragile but rather have a little heft and a rounded, tactile sensuality that encourages one to hold and caress them. One can imagine his pieces being used in English and Irish pubs of times past. In short, Simon's glass "is an intriguing hybrid of antique and modern, elegant and utilitarian" (Johnson, 1996: 21).

\section{The Early Years}

The story of Simon Pearce began in London where he was born in 1946. When he was four years old, his family moved to Shanagarry in rural Ireland. His father was, in Simon's view, a mixed role model. He changed careers about 5 times, eventually ending up as a potter. One thing Simon learned from him was "never be afraid to change your career." His father left London and a very successful printing business started by his own father. He was basically an early hippie. He moved his family to rural Ireland and was quite poor. He left London, its glamour, the family business and a future of plenty. In Simon's words, his father chose "quality of life over quantity of life in terms of money and all the trappings that go with it."

Simon began his formal education at the local national school where the teachers told his parents that he would never be able to do anything besides light the hearth fire and plant trees, both of which he loved doing and did very well. But his parents thought he should have more than that, so they kept sending him to different schools with the same results. Basically, Simon recalls, he was unteachable. He ended up in a Quaker secondary school in Waterford where he lasted three years and then was expelled. He notes that he never passed an exam in his life. The expulsion was not a crushing blow to his self-confidence because his parents never told him about it. "I had always hated school and I'd always wanted to leave school and every year I was told no you have to go to school. Then one summer I said I wanted to leave school and my parents said okay you may leave school. At that moment, I thought, God that was easy. That's the best news I've ever heard." It was eight years later when he was 23 that he learned he'd been expelled. He overheard his father telling someone about it at a dinner party.

One of the reasons he did so badly in school was his dyslexia. No one knew about dyslexia then. Not surprisingly, academics were stressed in school. What Simon wanted to learn were practical things: how to weld and other mechanical skills. "I was okay at math. I was terrible at any languages because of my dyslexia. History did not interest me. Geography did not interest me. The things I was interested in I was quite good at it. If you were an academic, if you wanted to become a lawyer or a doctor or something like that, probably the academic system was quite good." Ireland has one of the highest levels of education in the world. It has high academic standards. Simon notes that, "it's not for people who want to do anything unusual or creative or in my case start my own business."

"Dyslexia is an advantage in life," in Simon's view. "People go to college with no idea of what they want but they get a degree and it becomes a ball and chain." Simon says that his dyslexia forced him to analyze what he really wanted, because he had to work so hard to get it.

At 15 he went to work in his father's pottery. His father, Philip, and his grandfather were master craftsmen, the former in pottery, the latter in printing. His father studied at the London School of Printers before turning to pottery. In the seaside village of Shanagarry in County Cork, Ireland, Philip founded Shanagarry Pottery. He and others like him helped revive the handcraft movement that had given way in the $19^{\text {th }}$ century to machined, massproduced products. In the tradition of the time, Philip never put his name on anything, just Shanagarry Pottery. Simon recalls him as a little country potter. With his older brother, Stephen, Simon worked in the pottery for two years before heading off to New Zealand to study pottery making further. Stephen went on to found Stephen Pearce 
Pottery, in Shanagarry.

At 19, Simon left New Zealand and hitchhiked back across central Asia over the Kyber pass, through Kandahar, Afghanistan, the Mid-East, across Europe, and back to Ireland where he spent a little more time in his father's pottery. Wanting to start his own business, he moved from his parents' house and set up his own pottery called Bennettsbridge, in a village of the same name. The shop did well and within a year he had enough money to buy a little house and renovate it.

\section{From Pottery to Glass}

Though somewhat successful, Simon was restless and wanted to get into the glass business. "Everybody was a potter. Turn over a rock, and there's a potter under it," he explains. "I was collecting antique glass at the time, simple, everyday glass, the kind you find in an Irish pub. I loved the individuality, the uniqueness of the pieces, the little flaws and imperfections you could see-you don't see that in machine-finished glass-and I wondered why no one was making it anymore" (Johnson, 1996:20).

However, Simon found that the glass business was extremely difficult to get into. "It was a totally closed shop in Europe, the glass factories wouldn't let you in. They wouldn't answer letters. I wrote to 20 glass factories all over Europe and nobody would let me in. Most did not even reply and if they did it was negative. It was very secretive. It still is. They won't tell you anything about it, it's considered rude to talk about it. Today there are a lot of studio glassmakers. It's a whole different world now, but in those days it was very difficult."

Simon managed to get into the Royal College of Art, a well-known art college in London, through the back door. A professor there liked what Simon wanted to do. Simon knew the kind of glass he wanted to make. While a lot of people were making pottery again, no one was making glass the way they used to make it 200 years ago, which had individuality and character. The industrial revolution had basically cut it off. It was still being hand blown, but it was machine-finished and lost the quality that Simon really liked in it. That's what Simon wanted to make.

He recalls that he hadn't a clue what he was getting into and how difficult it would be to learn what he needed. Shut out of the European factories, he set out to learn glassmaking at the Royal College of Art. "Being skeptical of colleges, I never felt you could learn a skill in a college. If you wanted to learn to make something with your hands, the place to learn it is the factory where it is being made. Sure enough I got into this college and if I had stayed there until I was 50, I would never have learned to blow glass." But it acted as a steppingstone. He got into another college in Holland but it was the same story. Then he went to a factory in Holland called Leerdam. "I knocked on the back door, went around and met the foreman, told him I wanted to work in his factory, I'd sweep the floor, do whatever, and he let me in. I discovered the secret was not to write letters or not to try to go in the front door, but to arrive and talk to somebody on the factory floor, and you could nearly always talk your way in."

After Leerdam he worked in factories across Europe. When he got to Scandanavia it was like night and day, everything changed. Scandanavians told him and showed him everything. They were totally open. He ended up in an Orrefors factory in Sweden. They had a glass school within the factory to train glassblowers. He became a skilled glassblower. But Simon needed to learn more than glassblowing. He needed to learn how to build the furnaces, all the technology, how to melt glass, how to mix glass, the recipes, everything. He was there for about 8 months.

In 1971 he returned to Ireland ready to set up his business, thinking he knew enough to get going. He didn't. It was a struggle. His father had given him his inheritance, which was $\$ 10,000$. Simon knew that was all he could expect. His new business blew through that quickly. For example, he built and rebuilt his own furnaces nine times before getting it right. He had three people working with him and did \$11,000 in sales the first year. Survival did not come easily. It took about 7 years to develop the business so that the bank wasn't calling him every Friday night. 


\section{"Can Do" Attitude}

When he started his business, Simon did just about everything: built the factory, did the plumbing and the wiring, built the furnaces and the equipment, designed the glass, sold the glass, and opened the stores. "People had been asking me after I started this factory, 'how did you do this, why were you able to do all this, how did you learn to do all this?' Nobody had ever taught me or shown me anything. So I asked my mother, 'Lucy, people ask me about why I am able to do these things.' She said it was her way of educating. She said, 'It's what I believe education is really about, it's about a child's ability to believe in himself. For example, Simon, when your bicycle was broken, most parents would take the bicycle to a bicycle shop to get fixed.' She would never do that. A bicycle is just one example of thousands of different things. She would keep an eye on us and we would mess with the bicycle until she would see us start to get frustrated. She would say, 'What's the problem?' You'd say well the chain's broken or the pedal's broken. She would say, 'Here, here's some money, get on the bus, go into Middleton, the town ten miles away and get the part and bring it back.' And we'd fix it. It never occurred to us that we couldn't do anything, because nobody ever said to us or showed us in anyway that we couldn't do something. So everything that we wanted to do, we did. It never occurred to us at any stage, my brother's the same, growing up that we couldn't do something. If we wanted to start a glass factory, we started a glass factory. If it needed wiring, we wired it.”

What Simon finds extraordinary about society, past and present, is what he calls the sadly pervasive "do's and the don'ts syndrome." "A good example of it, and there are millions of examples," according to Simon, "is when parents bring their children into our stores. The first thing they do when they open the door is say 'don't touch.' The message they are sending to the child is you're not able to pick the glass up without dropping it, you're not smart enough, you don't have the ability to. It's the same with everything, 'don't touch the hot stove,' don't, don't, don't. We lived in a 3-story house. When my brother and I were about 7-8 years old, we would climb out onto the roof. My mother was so terrified that she would get in the car and drive away because she couldn't stand to be there. But she would never say don't or can't. She totally believed. This is the thing about creativity. I believe that everyone has exactly the same ability to be creative. I don't believe there is any difference in anyone. We all may have different areas where we will excel or it will come out. But the problem we all have is the idea or the notion that we have gained since the day we were born: I don't have the ability to or I won't be good enough or I'm not able to and it just goes on and on. It's the reason why we have name brands, it's the reason why we have Ralph Lauren who can sell a $\$ 40$ shirt for $\$ 140$, or we have Tiffany to sell a piece of Polish glass that cost them $\$ 5$ for $\$ 100$. It's because people are afraid to make the wrong choice, they don't believe in themselves. So they go out and they get the reassurance from the name brand Tiffany or Ralph Lauren. There's no such thing, as far as I'm concerned, as a good or bad design. How can something be good or bad. The idea that it's good or bad is completely nonsense. But, if you don't have confidence in your ability, it's because of how society has created this fear in you, you're afraid to say, 'Oh, I like that, it's kind of nice.' I look at People magazine, where they have the 20 best and 20 worst dressed people. What does that do for our confidence to go out and buy a piece of clothing or anything?" In Simon's view, creativity is there in everyone and the key to it "is where and how we get the confidence."

For Simon a classic example of confidence was Savador Dali. "He was a fairly wild man, great guy, incredible taste, and incredible confidence in whatever he did. Half his thing was confidence. I don't know if this is a true story, this story was told to me by and architect, a good friend of mine, I never had it verified, it doesn't really matter, but I believe it's true. Salvador Dali was hired by Cartier of $5^{\text {th }}$ Avenue to do a store window for them. They wanted something really special and Salvador Dali is a big name. So they hire Salvador Dali, he flies over, gets in a cab at Kennedy Airport, drives to $5^{\text {th }}$ Avenue, gets out of the cab, takes a brick out of his bag and hurls it through the window at Cartier which is full of diamond necklaces and broaches and all the rest. The sirens go off, the police come and everything. He says, 'Ok guys, get a piece of glass and put it over the window, don't touch anything.' And there's this window with this jagged glass, this brick, all these diamonds, all this broken glass, the most incredible window you could ever create, plus all the publicity. That is the ability, the courage, but really just the confidence in what he believed in. How many people would have that confidence? That is on one extreme." Cartier loved the window and the publicity. 


\section{No Formulas}

For Simon there is no formula for creativity though it seems to him that many people are looking for one. Creativity for him is to walk away from everyone else's views and formulas, to be truly and utterly alone, to walk away from every book, guide, teacher, or guru, to see things for oneself, to dare to look at everything around one without fear and without formula. "The only way you can create is when it comes from you," he says. "You don't need somebody else's formula. What you need is to believe in yourself and know that you've got it in you and believe that you can do it. For example, my brother, Stephen, a lovely fellow, is a potter, a very creative person. He wanted to take up oil painting. I saw his early attempts, they didn't do much for me. He had this friend in Dublin, a famous, well-known Irish painter called Mick Mullicanty, really wild guy, off the wall. So he called up Mick and said he wanted to learn to paint, oil paint. Mick says, 'Alright Stephen, come up to Dublin, I'll teach you to paint.' So Stephen goes up to Dublin, four hours on the train and he goes to Mick's studio. And Mick says, 'You want to learn to paint? I'll teach you how to paint. You take the f*in paint and you put it on the f*in canvas, that's how you paint, now go home and paint.' Stephen went home and took 20 canvases, bought some oils, and went off to Italy. A month or so later, he brought his paintings back to Ireland and wanted to show them to me. I was a little nervous because he is my brother. So he starts bringing out these canvases and they were gorgeous. They were unbelievable, just beautiful, incredible work. He could have gone to art school, he could have studied all the masters, and he could have learned all the techniques. By the end of it, he probably would have been so paranoid, so terrified to try and actually paint after having seen how everybody else for thousands of years had done it so wonderfully. All his vitality and power would have been drained. My guess is he wouldn't have done anything like what he created. Ok, he might not have mixed all the paints perfectly and got the pigments all right and the shadows, but the stuff is incredible and it's his first shot. That is just someone knowing and believing and having the confidence in his ability to do it." Simon acknowledges that it can be a bit scary to walk away from ones teachers and from doing things the way one has been taught. "But as long as we keep doing them that way, we're doing it somebody else's way. It's not us. It's fear of doing our own thing. It feels safer trying to do it somebody else's way."

Similar to the way Mick told Stephen to do it, Simon started by opening his sketchbook and drawing some wine glasses. Then he started making them, looking at them. Sometimes he'd get it right, something that pleased him right off. He would blow them himself. He was a glass blower and a glassmaker for 25 years. But he never studied anybody else's glass, never studied design, and never studied anything in terms of shape or form or creativity or drawing. He admits that he's influenced by things around him. "I don't think there is any way we could not be. We walk around, we see things, we like some. If we like something it automatically influences us.

On the issue of where he gets his ideas and are they original, he says, "I personally think the whole idea of trying to make original things is nonsense. Any shape or form you make, chances are, somewhere in the last 5,000 years, someone's made it." He recalls having designed a vase and made it in Ireland only to find an identical one in a London store a week later, as if it had come out of his mold. He recalls thinking, "I'm not going to make it if somebody else has made it." That was when he was 25 . "Today," he says, "it wouldn't cost me a thought. That idea came from me, it was mine, I made it, and somebody else has made it, so that's just the way it is. Of course, I think we actually get influenced in our subconscious. Sometimes when I've designed something I start to think, 'wait a minute, did I see something like that somewhere, sometime?' I don't worry about it anymore. I just design the things I like and not where the ideas or influences have come from. Sometimes I think the things I design are probably totally original and sometimes there maybe a subconscious thing I've seen. I'm not interested anymore in trying to figure that all out. It's too difficult."

\section{Just Clear Glass}

"I'm influenced by white. That shows in my glass because I only make clear glass," Simon points out. At least that was the case until recently. He and his glassblowers are doing an experiment with green glass, which he now likes. "Up until now, if I made a bowl to put fruit in or a wine glass, it would be clear. One of the greatest qualities glass has is its clarity. If you're going to make it green, then we make green pottery or whatever. But as soon as you have a beautiful clear piece of glass, it's the one unique property that glass has is that its clear. It's got some other unique properties, but that's the most obvious. When you put wine in it, it looks beautiful, I think, I 
mean the color of the wine. If you put the same wine in a green glass or a blue glass, to me you've lost it. But that's just personal.... If you like to make green glass, it's as good as my clear glass."

Making clear glass is one of the hardest things in the world to do but that was what Simon wanted to do. "It's incredibly difficult to melt high quality glass. To melt poor quality glass is easy and it's not very expensive. But high quality, clear glass is unbelievably difficult and there are very few people doing it in the world. There are the big companies like Steuben, but little people like us are very few because it's so difficult and expensive. There were many, many times that I said, 'Simon, you are out of your mind, you are crazy.' But, because I had this belief that if I created this thing that it would give me happiness, I did it. It's a bit like trying to find the bottom of the rainbow for the pot of gold. You'll look pretty hard if you really believe it's there."

\section{His Dream}

What motivated him to do this? He started with a dream, an idea, that he could create a successful business with his name on it, make a lot of money, and even garner publicity and fame. In the crafts industry, artisan anonymity has traditionally been the rule. Usually only an impersonal company name goes on the product. Yet, when Simon was ready to start his glass business and was looking for a name, he took his cue from two great potters of the early $20^{\text {th }}$ century, Englishman Bernard Leach and Japanese Shoji Hamada (Johnson, 1996). "Leach and Hamada both associated their names with pottery, and they could therefore command a higher price for their work," Simon recalls. In his view a name shouldn't make any difference. "A beautiful thing is a beautiful thing, regardless of whose name is on it," he says (Johnson, 1966: 22). But putting ones name on a piece adds value; it does matter to the public. For Simon it also meant never having to compromise on quality, which to him is the essence of both his business and his life. "After my family, the most important thing to me is the quality of my product" (Johnson, 1996: 22).

"If I got all that [money and fame] and I married a beautiful woman and I had a beautiful family, I'd be happy. I think it's where so many people start out with this idea that if I can do all of these things, get all of these things, I'll be happy. So low and behold, I did it all, I got it all about 5 years ago. Then one day I realized Simon wasn't happy. I really created the perfect scenario. I got everything that I dreamed of. I had houses in Vermont, houses in the Bahamas, an airplane, the whole shebang, beautiful wife, four beautiful boys. One day I realized, I was not one iota happier than the day I started, in fact, less happy. That was really a dramatic thing to experience and to feel and to realize that you can't create happiness outside you. It doesn't work for you. That was really the drive that started the whole thing, made the whole thing happen, this belief that happiness could be achieved outside of myself."

\section{Market Research and Customer Preferences}

Simon has never done market research to find out what people like in glass. He's not sure if, in the beginning, he was stupid or stubborn or naïve or whatever. "If you're brought up and if you start out with the belief that anything you want to do you can do, it doesn't occur to you that it won't work." When he came back from Sweden, after spending time working for Orrefors, to build his factory in Ireland, he stopped in London. He had made some samples of the sort of things he wanted to make. They were pretty crude, but were a good representation of what he was going to be producing. He went to the three best glass stores in London, Harrods, the Royal Trading Company, and Liberty's, who all had very good glass departments. He met all three glass buyers and they each said, "We have no interest, our customers would have no interest in those, we would not buy them." So he went back to Ireland and started making them. Within three years, all three stores wrote to him wanting his glass. None of them remembered his first visit. By then he'd been written up in magazines and newspapers and had had a lot of publicity. In Simon's view, those buyers had no belief in themselves. They looked at the product and they judged it from what they thought society (the market) would like. Simon did not (and does not) do any market analysis. He just made what he liked, even though many people told him not to. Asked if maybe he had a little luck, he says, "I have no belief in luck. ... You just make your luck." 


\section{From Ireland to Vermont}

"Many times in the early years we ran out of money and the banks were trying to foreclose. It was just crazy how difficult it was to get the business going in terms of making money. Then when I got the whole thing running properly in Ireland, and it was just starting to work and be successful and make some money, I said, 'alright we're leaving, we're going to America, I can't stand it any longer.' So we closed the whole thing down, sold it all off and moved to America and started again. The reason for that was that the business climate in Ireland was so difficult that I found that I was spending most of my time dealing with problems, petty problems, ridiculous little business problems, things that you take so for granted in this country. Like I applied for a second telephone line and they said two years. And every time you wanted to dial a number in Dublin, which was the capital and just an hour away, you might dial it 8 times before you get through. You just sit there getting frustrated. In using the post office, we had to take the parcels to the town, we had to take them up the elevator and sort them and stamp them if we wanted them to go within a week. Finally I said, 'you know I'm twenty whatever,' by that time I was 28 . I don't want to live the rest of my life doing this. It wasn't working for me personally. I wanted my life to be involved in creativity, running the business, and so on."

In 1981 after 10 years in Ireland, he moved to America where he built a successful business over a 20 year period, starting in the little town of Quechee, Vermont. He went from the three Irish glass blowers he brought with him when he came to America to 350 employees. When he moved from Ireland, there were three things he was going to have because he was closing down a perfectly good business. He believed the world was his oyster and he could chose to do whatever he wanted. The three things he wanted were somewhere beautiful to live and work, somewhere where we could make his own electricity because in those days oil was $\$ 30$ a barrel and glass is highly energy intensive, and, lastly, somewhere where he could do a good retail business because he had learned the value of doing retail himself, making and selling a product himself. He found an old woolen mill in Vermont, on the banks of the Ottauquachee River, and it had all three. Simon was in heaven, but not for long.

The beginning in Vermont was extremely rocky. Simon recalls that the key during those first rough months was "the ability to hang in there long enough for it to happen. Being able to run lean and mean and to do a lot of the stuff yourself and to just do whatever it takes to just keep the doors open long enough. At the same time, Simon refused to change his glass designs and products to match customer demand. "If I don't like it I won't make it. There's absolutely no question. That came up when we started in this country. We started our store in Vermont and it was very rough going. I totally underestimated the cost of running a business in this country. I thought I knew it all coming from Ireland. It was night and day. I understood how to make the glass and such, but the overhead and the cost of doing business was totally different than I'd expected. We were right back in the trenches. It was like how are we going to survive? And everybody said I had this big store set up and only about $10 \%$ of the people who came in bought anything because it was not their taste, they weren't used to it, it was more expensive than they were used to. So everybody said you've got to sell other products, you've got to sell T-shirts, you've got to sell the things that tourists will by. They're here, they're in your store, you have got to sell to them. I said no, we're not going to sell anything that I don't like or I don't believe in. I don't care if we go out of business. I'll go and do something else. I'll pump gas or whatever I need to do, I'm not doing this just for the money. I'm doing it for many other reasons. Money is one of them. I'm not interested. I think it's one of the great downfalls of many, many businesses. People start off with a great idea and they get into it and then things get tough and they say, well we'll compromise the quality, we'll compromise the so on. And of course, we all compromise, I've compromised, but you don't compromise the guts of it, the real main thing. You may have to do some little things on the edge just to squeak by. But you don't really compromise what you believe in. It's one the most exciting challenges to me--to succeed and not to really compromise."

Indeed, Simon's work has never been for the mass market. Today a large vase retails for $\$ 105-\$ 180$, a wine glass or beer tankard for $\$ 60$, and a large bowl for $\$ 160-\$ 240$. Yet, many people have acquired a taste for his work, including the rich and famous. Jacqueline Onassis was a regular customer. Many of their customers become repeat customers and most new customers learn about Simon Pearce glass from their friends.

In 1984 Simon started his own pottery in The Mill in Quechee to compliment his glassblowing operation. 
He approached his designs with an eye for history, utility and grace. At present there are three lines in production, celadon, black, and white. His potters use a combination of new methods and traditional throwing techniques that date back thousands of years. As a result, each piece has its own distinct character.

Most people didn't believe he could have a successful retail business there. What Simon wanted to do was create a destination, something so special that people would come to it. He believed that if people are going to go somewhere for a day's outing or couple of hours drive, food is probably a big attraction. People remember a good meal. In tiny Quechee, there weren't many good lunch restaurants. So he got into the food business. At first, the restaurant was a fiasco. But he's come through it and learned some hard lessons. He's learning again because he opened a second restaurant in Windsor, Vermont, which is now struggling. But the original restaurant is now very successful. Typically, people drive to the renovated mill in Quechee from Boston or from nearby New Hampshire, Connecticut, or New York and they watch the glass and pottery being made downstairs. Upstairs they buy glass and pottery in the large, airy, sunlit retail store, and then they have a meal in the restaurant, overlooking the picturesque Ottauquachee River. They'll often spend four hours in the building. The children walk around and can also watch a weaver from Ireland making rugs. It's a destination and it's educational. The restaurant was necessary to create the full ambience. In Simon's words, "Of course, I had to do a good restaurant because there's no point having bad food and beautiful glass. You have to have good food and good glass." The restaurant only uses the glass and pottery his people make. Having the three together - the restaurant, glassmaking, and retail store-has created a synergy. That one store sells as much glass as nine of his other stores combined.

\section{The Current Situation and Practices}

Today Simon employs over 40 glass blowers, most of whom are Americans, specially trained to meet the challenges of fashioning handmade pieces in clear glass. Some are high school graduates and some are Dartmouth graduates. Finding and training them has not been easy since most Americans don't want to spend anywhere from two to five years learning the skills. Others bring their specialized skills from Sweden and the Czech Republic. Creating in teams of two, they share the delicate tasks of handblowing and hand finishing.

Among Simon's business practices, is the fact that his employees are well paid by local standards. Another is his unusual breakage policy: if a child breaks something, it's on Simon. In terms of hiring, he does it largely by instinct. He is not impressed by credentials but by performance. He's not anti-education or professional degrees. He just wants to see results. People need to show him they can do the job. He used to be fooled by credentials but no longer. Performance is also the basis for promotion. A woman who began as a waitress in his restaurant has become their West Coast sales representative because she demonstrated enthusiasm and ability. "It was a great move," Simon says. "She's been incredible" (Johnson, 1996: 23). Finally, he does not let problematic behavior determine policy or practice. When employees steal or fail to repay a loan from the company's loan program, he does not overreact. "If somebody in the company does something wrong, there's always a manager who want to lock things up or cancel the loan program. Why? Why would you punish the vast majority for something one person does wrong? It's a terrible mentality, a mentality one has to keep on top of" (Johnson, 1996: 23-24).

Simon allows his employees to make their own glass on their own time using his equipment. He also lets them submit designs for glass pieces to him. If he likes a design he'll put it into production and the person gets paid for it. He notes that most people don't submit designs. "They are afraid that if I don't like it, it will mean there is something wrong with it. Whereas it's just that I don't like it, it doesn't mean there's something wrong with it. When you start to think about it, there can't be any wrong. It's just a different object."

Simon delegates the day-to-day running of the company to others. He trusts his people and is available to them just by a phone call. His days are his own with the exception of the occasional business meeting. That leaves him free to dream and create and to decide what he wants to do at the moment. That doesn't mean he's not busy. "I like to have six balls in the air at once-it's a trait of dyslexia." "I have no fixed schedule in my day. I might drop the boys (he has four sons, three of whom are dyslexic and the fourth has Down's syndrome) at school, go down to Windsor, talk to a manager, design some glass, go home and work out, have lunch, go bicycling with my wife" (Johnson, 1996: 24). 
While making and selling glass remains his core interest and business, he now sells pottery made in his own Vermont facility and in the Irish workshop of his brother, Stephen. There are hand-woven rugs by the son of a man who made rugs of Simon's father and there are table linens to complement the glassware (Johnson, 1996: 21).

Simon's business situation has gone full circle from initial struggle, to steady strong growth and success, and now back to serious struggle (albeit, struggling to maintain a 30 million dollar a year business). He notes, "We're in quite serious trouble at the moment because of some decisions I made a couple of years ago. So we're back in the trenches right now, just trying to survive." With the economic recession and with September 11, sales halved at a time when SP couldn't afford them to drop one percent, much less fifty. He ran the business for thirty years and never once had a year when sales were less than the year before through all the slumps and the economic crises of the last thirty years. That's changed. For many years he was in the mode of believing that he could create his happiness through the business. He says he "was like so many people who get caught in this idea that I don't need ten stores, I need two hundred stores. I need to be coast to coast in every city. We were on that bandwagon. Then about five years ago, I realized I don't want to do there, I don't want to go there, that's not what I'm interested in. But, by then I'd put some things in place and made a few decisions that we're living with now and that are pretty serious."

\section{A New Dream}

Money is no longer a strong motivator for him. In his words, “once you realize that [money] doesn’t make you happy, then a lot of the motivation is gone. The problem as I see it with this type of motivation is that it is pleasure. What I've learned is that what we all do is mix up pleasure and happiness and pleasure of the external things. Buying a new car, sex, power, money, those are all external things. What I find is that, the problem with pleasure is that you have it and then its gone and then you need something else. You immediately want more pleasure and that's what happens in business. I'll never forget when we did our first million dollars in this country in sales. I'd died and gone to heaven, I couldn't believe it. I'd just been in this country for ten years or whatever it was, seven years, five years, I've got a million dollars in sales. And before I knew it, I needed to do 5 million and 10 million and 15 million, up to 30 million or somewhere, where ever we got. Then what I find is when I have a good month I'm feeling great and when we have a bad month I'm feeling down. It's what I call the yo-yo syndrome. I see these people who build these businesses, 100 stores, 200 stores, and I'm thinking, I know that feeling, I know what they're doing, I know why they're doing it."

Simon started looking inward and that's where he found happiness. When he started to realize the difference between happiness and pleasure, he could see pleasure for what it was. Having things like money, a new car, or sex is great. They're pleasures. But soon the good feelings fade. They don't bring happiness. Once Simon figured that out, he realized that he couldn't find real happiness through this business. He started to look at things differently. He stopped needing the business to be any bigger. It was perfect the size it was. What was the point to 30 or 60 or 100 million or 200 million dollars? In Simon's words, "I'm very lucky, I think, because most people if I say this to them, will say, 'yeah it's all very fine for you to talk, you've got it all.' What's wonderful for me, why I feel so fortunate is because I've got it, I can see it isn't the answer. It's probably much harder to see that it isn't the answer if you haven't got it. It's the old win the lottery syndrome: if I win the lottery I'll be happy. Someone who's won it telling you it doesn't make you happy doesn't really help the person who hasn't won it. It's exactly the same thing."

Simon went through a stage where he thought he would like the business to be smaller but now believes that the size is unimportant. To him, it's the need for it to be different than it is that's the problem. "Now that it's at a size, all that I need to do is make sure that its properly run and organized and I can have my freedom. So I can have in place a team that runs a $\$ 30$ million business just the same as a $\$ 20, \$ 10$ or a $\$ 5$ or a $\$ 50$. The problem is if I had a need for it to be different, smaller or bigger. The key is to be happy with it where it is, is what I believe from my personal experience and life."

He feels fortunate to be at a point where he doesn't want or need it to be any different than it is. He doesn't wish he had found it out ten years before. "We find out when we're ready to find it out, that's the right time to figure 
it out. But I'm certainly glad I found it out now and not when I'm 70 or 80 . That would have been an awful waste of the last twenty years of my life."

Simon loved the actual process of blowing glass. It was some of the happiest times of his life when he was on the bench making glass. It was slightly ruined for him "by always having the little worm in the mind saying this isn't enough." Simon believes that had he been in a place in his head where it was totally enough just to be making glass, it would have been much purer and he would have been much more satisfied. But always there was the feeling somewhere in the back of his mind that really what was enough was making the business successful, making more glass, making the business bigger. In Simon's view, "So many people go through their lives thinking that what they're doing isn't quite enough. It's really a means to an end, it's the way, once we've done it and earned the money, that's what is going to make us happy as opposed to the process." He likes the message in the book, "The Power of Now" which is that "this moment is what it's about, this is it right here. What we spend most of our time doing is living in the future or the past, this is never enough. We're never here. Our mind's always somewhere else. Whether it's glass or pottery, I'm sure I'll be doing something else, now that I'm able to look at it differently."

\section{References}

1. Johnson, S. "Simon Pearce." The Boston Globe Magazine, (1996): 20, 23, 25-27.

2. Interviews by the authors with Simon Pearce.

\section{Case Discussion Questions}

In responding to each of the following questions, support your points or assertions with facts or examples from the case. Where appropriate, use concepts from theoretical and empirical articles to frame your responses.

1. What expertise or knowledge did/does Simon have, fostering his creativity and innovativeness?

2. Was Simon intrinsically or extrinsically motivated to be creative and innovative?

3. What individual factors does Simon possess that contribute to his creativity and innovation?

a) Personality factors

b) Cognitive factors

c) Creativity skills

4. Identify any situational supports for or constraints to his creativity and innovation?

5. Why has Simon been successful creatively and financially?

6. What made Simon a successful entrepreneur?

7. What should Simon do now? 